\title{
Information Technology Adoption in Botswana Secondary Schools and its Implications on Leadership and School Libraries in the Digital Era
}

\author{
Angelina TOTOLO, University Lecturer, Department of Library and \\ Information Studies, University of Botswana, Botswana \\ (Currently at Florida State University, \\ College of Information for PhD. studies)
}

\begin{abstract}
The objectives of this paper are to examine the principals' transformational leadership qualities and to juxtapose this to Information Technology adoption in Botswana secondary schools. Using David et al. (1989) Technology Acceptance Model (TAM), Todd's (1999) transformational leadership constructs, and qualitative open-ended questions, a research tool was formulated to establish the perceptions of school heads in 10 urban and 14 rural schools, about computer technology acceptance, the role of the school library in the integration of computers in the school and transformational leadership. The findings point to a trend towards computer acceptance and transformational leadership, albeit some indications of computer anxiety, some feelings about the lack of computer usefulness and ease of use, as well as leadership issues, like the lack of functional school libraries. One of the most relevant findings was the positive correlation between perceived ease of use of the computer statement to some leadership constructs.
\end{abstract}

\section{Introduction}

The introduction of information technology (IT) in schools and media centers requires effective policies and leadership in order to guide the process of adopting new technologies. IT introduction and adoption has been the subject of worldwide discussion as evidenced by the extensive literature examining what factors influence its adoption (Baskerville and Pries-Heje, 2001; Comin and Hobjin, 2004; Kukafta et al.1983; Legris, Ingham and Collerette, 2002; Rogers 1995). Similarly, leadership in the information era is a burning issue today. (Todd, 1999; Doyle and Smith, 2001; Bolman and Deal, 2003).

In 1997, the Botswana government set up a Presidential Task Group to work on a vision for Botswana called the Long Term Vision 2016. Mentioned in the Vision is the desire to produce citizens who are informed and are able to use information effectively. Prior to the Presidential Task Force, the Botswana Government introduced reforms documented in the 1994 Revised National Education Policy. One of its objectives is to equip all secondary schools with a computer laboratory. This objective has been achieved as all schools in the country have a computer laboratory, but there is a need to find out if the computers are integrated in the learning process. An investigative study of the school heads' perceptions of computer technology, their leadership characteristics, as well as how they intend to use the school library in their 
quest for computer integration in the learning process is one way to respond to this question.

\section{Significance of the study}

In addition to studying the integration of computer technology to determine the impact of government policy in schools and to inform strategic planning, it is also important establish the extent of its impact on learning because information technology is very expensive to install. To this end, a study was carried out to answer three research questions.

First, what are the perceptions of the principals towards adopting and using computers?

* Second, what characteristics do principals display towards transformational leadership?

* Last, what are the principals' perceptions of the usefulness of the school library in computer technology integration?

\section{Literature Review}

The literature consulted is divided into four areas: the theoretical framework of the study, transformational leadership, information policy and the role of the school library in the digital era.

\section{Theoretical framework}

This study uses Rogers' Meta theory, Innovation Diffusion Theory (IDT) (Rogers, 1995). Within this Meta theory are four theories: Innovation-Decision Process, Individual Innovativeness, Rate of Adoption and Perceived Attributes. (Surry, p.3). This study uses the last theory, Perceived Attributes and specifically one of the most used models of diffusion, Technology Acceptance Model (TAM), proposed by Davies (1989). The Perceived Attributes theory was introduced by Rogers to explain users' perceptions of innovation acceptance and adoption, in relation to levels of anxiety about an innovation, the perceived usefulness (PU) of an innovation and the perceived ease of use (PEOU) of an innovation. TAM is a model that has been used extensively (Agarwal and Prasad, 1997; Dishaw and Strong, 1999; Karahanna and Straub, 1998; Venkatesh and Davies, 2000; Venkatesh, 2000; Zhu, 2003) to explain the adoption of innovation. The technology acceptance variables that have prevailed in the Perceived Attributes literature include computer anxiety (Orr, 1993; Venkatesh, 2000), perceived ease of use, perceived usefulness, and intention to adopt. (Szajna, 1996; Venkatesh) According to Venkatesh, perceived ease of use has been defined as a person's belief that using a particular technology does not require too much effort. He goes on to say perceived ease of use is an important factor influencing user acceptance and usage behavior of information technologies (p.344). Perceived usefulness is the extent to which a user believes that a certain technology will enhance the performance in his/her job and has thus been closely associated with motivation (Venkatesh, p.348). 


\section{Transformational leadership}

According to Todd, "Transformational leadership moves beyond managerial and instructional leadership to providing schools with strategies necessary to cope with change"(p.1). Writing on the characteristics of transformational leaders, Todd says that they center on transforming the environment, developing a shared vision and strong philosophy, emphasizing school based management as well as keeping abreast with new trends and developments (p.1). Doyle and Smith (2001) share this view of transformational leadership. They describe transformational leaders as "visionary", people and "change agents" (p.8). Doyle and Smith argue that leaders emerge during a crisis or when there is a need to make an important decision for the survival of the organization (p.2).

Transformational leadership is therefore a very important part of the drive towards adopting and using computer technology in the school. School heads must be seen to be in the forefront of computer technology adoption and use. This entails having strong philosophies and policies in place to guide the process of computer adoption and effective use. Information policy offers the structure and the guidelines within which to function while leadership ensures the implementation of the policy decisions.

\section{Information Policy}

Several authorities on information policy (Carbo, 1998; Opeinheim, 1998; and Overman and Cahill, 1990), have pointed out that most information policies are incomplete and that as a result they fail to address all issues related to information technology adoption. Slowinski (1999) argues that legislators and other policy makers appeal to voters by proposing simple solutions for reforming education but those solutions do not deal with real policy problems like the utilization of technology in the learning process. He goes on to say teachers teach for state exams instead of utilizing technology in the teaching. The importance of the information policy as a tool that can bring change is brought into focus here. Though there are policies enacted, they lack completeness including the absence of strategies to use to achieve goals For example, the information policies have not been clear as to what levels of information technology to adopt. Is it learning about technology, learning with technology or learning through technology? (Law and Plomp; 2003)

\section{The role of the school library}

At the centre of the learning process in every school is the resource centre or school library. The resource centre is also known as the "heart of the school" (Information Power: Building partnerships for learning, 1998, p.1) because of its role in the learning process. In the information era, which is marked by an information explosion, resource centres are needed even more than ever before because of the complexities of today's technology and the myriad of opportunities that exist for e learning. Botswana's Vision 2016 has as one of its goals, the preparation of learners 
for lifelong learning. This is the same goal that school libraries cherish. This goal is also supported in Information Power: Building partnerships for learning, where it is mentioned, " A dynamic, student-centered library media program fosters information literacy and lifelong learning" (p.47). Writing on the role of the school library, Smith (2002) says, "School library media centers in the 2151 century can, and should be, hubs for increased student achievement and positive focused school reform" (p.87). The same concept is expressed by Harrison (2004) who views the school library as an "educational extension" (p.63) and as occupying "centre stage" in all learning in the school (p.63).

\section{Methodology}

No research has been conducted to understand the perceptions of the school heads in any of the five regions in Botswana, a country in Southern Africa, towards computer technology adoption, and how that perception relates to leadership and the role of the school library in technology adoption. The region studied included the urban area of Gaborone, the capital, and the rural area surrounding. The current study presents and applies the theoretical model: TAM as related to the determinants of system-specific perceived ease of use, perceived usefulness as well as anxiety towards computers. In order to relate the perceptions to leadership and school libraries, the questionnaire designed for this study includes both perceived attributes of computer technology adoption and the transformational leadership paradigms. The combination of these two theories is meant to assess if there is a correlation between the perceived attributes of computer adoption and use and transformational leadership characteristics

Based on the above constructs, questions were adapted from an existing pool of research questions on TAM to solicit the extent of the school heads' technology acceptance. The method of data collection was a survey. In October 2004, a pilot survey was administered to ten school heads. The pilot study results revealed a positive response towards the adoption of computers as well as transformational leadership qualities amongst the school heads, which differed from the literature consulted. A full data set was collected after altering the research instrument by changing the "yes and no" questions to a scale with five options; strongly disagree, disagree, not sure, agree and strongly agree for the TAM questions and very low priority, low priority, medium priority, high priority and very high priority for leadership questions. Also added to the instrument were two open-ended questions in order to capture the school heads' perceptions of the role of the school library in the integration of information technology in the school. The full data set was collected through a survey, sent to school heads in the South Central region in Botswana. The questions for TAM tested three constructs, computer anxiety, and perceived ease of use and perceived usefulness with regards the computer technology. The leadership questions tested the principal's perceptions of transformational leadership. Tables 1 through to 4 show the questions asked in the survey. 
The open-ended questions were:

* What in your opinion is the role of the school library in the integration of computers in the learning process?

* Who in your opinion should impart information literacy skills? Please give a reason for your choice.

Since the data collected is not a random sample of a larger population, but rather a purposeful sample, the sample may be described as a non-probability sample, in which the respondents were chosen based on the convenience, availability and reliance on available subjects (Babbie, 2001, p.179). Although the non-probability sample has limitations in terms of its inability to be generalized to the whole population, the data can be used to answer questions and hypotheses (Cresswell, 2002: p.167). This study included 24 participants. It is an explanatory correlational study because it aims at explaining the association between technology acceptance, leadership and the role of the school library as perceived by the school heads or principals. Since the data collected is not a random sample of a larger population, but rather a non parametric data set, two statistical analysis stages on the data were used: descriptive statistics such as frequencies, and percentages, to determine trends and patterns and non parametric data analysis using the Spearman's rho test, to explore if there was statistical significance between the independent variable: computer technology adoption to the dependent variable, leadership. The Spearman's rho is the non-parametric equivalent to the standard correlation coefficient in parametric data analysis. Content analysis was performed on the open ended qualitative questions in order to find the perceptions of the school heads with regards the role of school libraries in computer integration and learning in schools. The quantitative data collected was coded and analyzed using SPSS statistical software. The "agree and strongly agree" responses were collapsed into one response; and the same applied to the "strongly disagree and disagree" responses. This was done in order to make the percentages more likely to be significant because of the small data set involving only 24 respondents. Likewise, the very low and low priority and the high priority and very high priority were collapsed for the same above reason. The results of the correlation from Spearman rho are based on the variables that summarize the statements on anxiety (I have control over using the computer), the PU (Overall I find computers useful in my job), and PEOU (Overall I find the computer easy to use). For visionary leadership, the variables chosen for the correlation test were based on the vision statement, the school library facilitating access, imparting information literacy skills and computer integration in the classroom, in line with the purpose of this study.

\section{Discussion of findings}

Gender, Age, and Education

Of the 24 respondents, $58 \%$ identified as male, and $17 \%$ identified as female and $25 \%$ did not specify their gender. In terms of education, about $58 \%$ hold a college degree, including $25 \%$ who hold a master's while $1 \%$ holds other qualifications, and about $13 \%$ did not answer the question. $13 \%$ of the respondents 
were between 31-40 years of age; about $42 \%$ were between 41 and 50, about $21 \%$ over 50 , while $25 \%$ did not respond to the question. Cross tabulations between age, education and gender did not yield statistically relevant analysis because of the small sample size.

\section{Computer Technology Acceptance}

The perceptions of the school heads towards adopting information technology were measured using the Technology Acceptance Model (TAM) as suggested in the literature consulted. The use of TAM in the past has been in determining the robustness of the model, (Szajna, 1996), the extension of the model (Gefen and Straub (1997) and predicting whether users will adopt new technologies (Venkatesh and Davies, 2000), the purpose of which it is put in this paper. Three levels of analysis were done, in keeping with TAM studies in the past, to test computer anxiety (Venkatesh, V. 2000), Perceived Ease of Use (PEOU), and Perceived Usefulness (PU) (Davis et a, 1989) The research question posed was: what are the perceptions of the school heads towards adopting and using computers? Overall the results of the study show a trend away from computer anxiety with percentages ranging from $12 \%$ to $29 \%$ reporting some computer anxiety and discomfort, as the results on Table 1 below show. On the questions on nervousness around computers, feeling at ease in computer training workshops, a sinking feeling when using computers, discomfort around computers and having control over computers, the results show about $70 \%$ and more saying that they do not have computer anxiety. These results tally with the results of the pilot study, which also revealed this trend towards comfort around computers. However not all the responses showed comfort around computers. The question on feeling threatened when other people talk about computers revealed $71 \%$ of the participants reporting that they do not feel comfortable when people talk about computers. This result differs from the rest of the questions on anxiety. This might be due to the strategy used to ask the questions, which deliberately mixed positive and negative statements, therefore, it is possible that the participants misread the question. Based on these results, it can be concluded that the majority of the respondents do not have computer anxiety but there is a certain level of computer anxiety, which has been labeled as technophobia in the literature. (Orr, p1) 
Table 1: Anxiety, discomfort around computers, and fear of computers.

\begin{tabular}{|l|c|c|c|c|c|c|}
\hline Variable & $\begin{array}{l}\% \\
\text { strongly } \\
\text { disagree }\end{array}$ & $\begin{array}{l}\% \\
\text { disagree }\end{array}$ & $\begin{array}{l}\% \\
\text { not } \\
\text { sure }\end{array}$ & $\begin{array}{l}\% \\
\text { agree }\end{array}$ & $\begin{array}{l}\% \\
\text { strongly } \\
\text { agree }\end{array}$ & Total\% \\
\hline $\begin{array}{l}\text { Working with a computer makes } \\
\text { me nervous, so I avoid using it if I } \\
\text { can }\end{array}$ & 80.8 & 16.7 & 4.2 & 8.3 & 0 & 100 \\
\hline $\begin{array}{l}\text { I feel threatened when other people } \\
\text { talk about computers }\end{array}$ & 8.3 & 16.7 & 4.2 & 25 & 45.8 & 100 \\
\hline $\begin{array}{l}\text { I feel at ease in a computer training } \\
\text { workshop }\end{array}$ & 4.2 & 16.7 & 4.2 & 54.2 & 20.8 & 100 \\
\hline $\begin{array}{l}\text { I get a sinking feeling when I think } \\
\text { of trying to use a computer }\end{array}$ & 58.3 & 20.8 & 4.2 & 12.5 & 4.2 & 100 \\
\hline $\begin{array}{l}\text { I feel comfortable working with } \\
\text { computers }\end{array}$ & 0 & 20.8 & 4.2 & 37.5 & 37.5 & 100 \\
\hline $\begin{array}{l}\text { Computers make me feel uneasy } \\
\text { n have control over using the }\end{array}$ & 8.3 & 12.5 & 12.5 & 58.3 & 8.3 & 100 \\
\hline $\begin{array}{l}\text { Computer } \\
\text { uncomputers do not make me }\end{array}$ & 16.7 & 4.2 & 0 & 37.5 & 41.7 & 100 \\
\hline
\end{tabular}

The Perceived Usefulness of the computer produced mixed results. Of the eight constructs tested, four revealed a trend away from usefulness of the computer in their work. The questions on the compatibility of the computer, the increase in job performance, and the computer supporting critical aspects of the job, all drew close to $80 \%$ and above in terms of the lack of usefulness of the computer to the school heads. The summary of the PU variable, which tested the overall perceptions, drew a $21 \%$ response away from computer usefulness and a 33\% of the respondents saying computers are useful. The interesting thing to note here, is that the majority of the respondents, $46 \%$, chose the "not sure" option. The other set of constructs under the PU variable on the computer making the job easier, increasing productivity and improving the quality of work, produced more than $70 \%$ respondents saying the computer is useful. This result probably reflects maturation amongst the subjects because computer technology is not new in Botswana; therefore some subjects are likely to be more computer literate than others. Overall, there are strong indications that not all school heads find the computer useful in their job. These findings have implications for computer integration in the classroom system and are in line with research in the literature pointing to low usage of computers. (Vinkatesh and Morris, 2000, p.115) The results are shown on Table 2 below. 
Table 2: Perceived Usefulness of the computer

\begin{tabular}{|l|c|c|c|c|c|c|}
\hline Variable & $\begin{array}{l}\% \\
\text { strongly } \\
\text { disagree }\end{array}$ & $\begin{array}{l}\% \\
\text { disagree }\end{array}$ & $\begin{array}{l}\% \\
\text { not } \\
\text { sure }\end{array}$ & $\begin{array}{l}\% \\
\text { agree }\end{array}$ & $\begin{array}{l}\text { \% } \\
\text { strongly } \\
\text { agree }\end{array}$ & Total\% \\
\hline $\begin{array}{l}\text { The computer is compatible with } \\
\text { other systems I use }\end{array}$ & 80.8 & 16.7 & 4.2 & 8.3 & 0 & 100 \\
\hline $\begin{array}{l}\text { Using a computer improves the } \\
\text { quality of what I do. }\end{array}$ & 8.3 & 16.7 & 4.2 & 25 & 45.8 & 100 \\
\hline $\begin{array}{l}\text { The computer enables me to } \\
\text { accomplish tasks more quickly }\end{array}$ & 4.2 & 16.7 & 4.2 & 54.2 & 20.8 & 100 \\
\hline $\begin{array}{l}\text { The computer supports critical } \\
\text { aspects of my job }\end{array}$ & 58.3 & 20.8 & 4.2 & 12.5 & 4.2 & 100 \\
\hline $\begin{array}{l}\text { Using a computer increases my } \\
\text { productivity }\end{array}$ & 0 & 20.8 & 4.2 & 37.5 & 37.5 & 100 \\
\hline $\begin{array}{l}\text { Using a computer increases my } \\
\text { job performance }\end{array}$ & 62.5 & 20.8 & 4.2 & 12.5 & 0 & 100 \\
\hline $\begin{array}{l}\text { Using a computer makes it easier } \\
\text { to do my job }\end{array}$ & 0 & 0 & 12.5 & 45.8 & 41.7 & 100 \\
\hline $\begin{array}{l}\text { Overall I find computers useful in } \\
\text { my job }\end{array}$ & 8.3 & 12.5 & 45.8 & 29.2 & 4.2 & 100 \\
\hline
\end{tabular}

Many respondents seemed to be unsure about responding to the perceived ease of use (PEOU) statements, judging by a "no response" rate as high as $12.5 \%$ in some cases, and the "not sure" response, which reached a $45.8 \%$ on the question of clear and understandable interaction with the computer. However, seven of ten constructs drew more than a $63 \%$ trend towards perceived ease of use. These constructs tested the ease of interacting with the computer, remembering how to do tasks on the computer and overall perceived ease of use. The rest of the constructs, on being skillful at using the computer and taking a lot of effort to become skilful at using the computer, drew a more than $42 \%$ trend away from perceived ease of use of the computer. This $42 \%$ from the 3 constructs and the previous $37 \%$ from the seven constructs above all showing a trend away from perceived ease of use of the computer shows that there are strong indications that some school heads do not find the computer easy to interact with or use. In particular, there is an indication that school heads think that they lack the skills for interacting with the computer. These results have implications for computer integration policy implementation. Literature in the field has pointed to PEOU as an impediment to adopting and using technology. (Venkatesh, Szajna) Table 3 shows the results below. 
Table 3: Perceived ease of use

\begin{tabular}{|l|c|c|c|c|c|c|c|}
\hline Variable & $\begin{array}{l}\% \\
\text { Strongly } \\
\text { disagree }\end{array}$ & $\begin{array}{c}\% \\
\text { Disagree }\end{array}$ & $\begin{array}{c}\% \\
\text { Not sure }\end{array}$ & $\begin{array}{c}\% \\
\text { Agree }\end{array}$ & $\begin{array}{l}\% \\
\text { Strongly } \\
\text { agree }\end{array}$ & $\begin{array}{c}\% \text { Ro } \\
\text { Response }\end{array}$ & Total\% \\
\hline $\begin{array}{l}\text { I find a computer cumbersome to } \\
\text { use }\end{array}$ & 45.8 & 20.8 & 8.3 & 8.3 & 8.3 & 8.3 & 100 \\
\hline $\begin{array}{l}\text { Learning to use a computer is easy } \\
\text { for me }\end{array}$ & 4.2 & 16.7 & 16.7 & 50 & 8.3 & 4.2 & 100 \\
\hline $\begin{array}{l}\text { Interacting with a computer is } \\
\text { frustrating }\end{array}$ & 29.2 & 45.8 & 4.2 & 16.7 & 0 & 4.2 & 100 \\
\hline $\begin{array}{l}\text { I find it easy to get the computer to } \\
\text { do what I want to do }\end{array}$ & 8.3 & 8.3 & 12.5 & 50 & 12.5 & 8.3 & 100 \\
\hline $\begin{array}{l}\text { The computer is rigid and } \\
\text { inflexible to interact with }\end{array}$ & 41.7 & 29.2 & 8.3 & 12.5 & 0 & 8.3 & 100 \\
\hline $\begin{array}{l}\text { It is easy for me to remember how } \\
\text { to perform tasks using the } \\
\text { computer }\end{array}$ & 4.2 & 12.5 & 4.2 & 50 & 16.7 & 12.5 & 100 \\
\hline $\begin{array}{l}\text { Interacting with the computer } \\
\text { requires a lot of mental effort }\end{array}$ & 8.3 & 20.8 & 20.8 & 33.3 & 12.5 & 4.2 & 100 \\
\hline $\begin{array}{l}\text { My interaction with the computer } \\
\text { is clear and understandable }\end{array}$ & 12.5 & 20.8 & 45.8 & 12.5 & 12.5 & 8.3 & 100 \\
\hline $\begin{array}{l}\text { I find it takes a lot of effort to } \\
\text { become skilful at using the } \\
\text { computer }\end{array}$ & 8.3 & 25 & 20.8 & 29.2 & 12.5 & 4.2 & 100 \\
\hline $\begin{array}{l}\text { Overall I find the computer easy to } \\
\text { use. }\end{array}$ & & 16.7 & 8.3 & 45.8 & 25 & 4.2 & 100 \\
\hline
\end{tabular}

\section{Leadership characteristics}

The second research question sought to find out the characteristics the school heads display towards transformational leadership. The results point to a majority choosing high and very high priority for eight out of eleven constructs, with percentages ranging from 75 to 96 . The high and very high priority responses were on imparting information literacy skills to students and teachers, integrating computers in the school for access and use, introducing computer use policy, as well as evaluating a computer integration vision statement each year. Worth noting too in this category is the lower percentages of 67 and 63 for combined high and very high priority on the questions dealing with drawing a vision statement for computer integration and involving all stakeholders in drawing the vision statement respectively. Also the medium priority for the two above questions is as high as $21 \%$. Therefore, the vision statement questions drew lower percentages compared to all the leadership questions. Another equally interesting response is the school library one, on making the school library facilitate computer access. The response was $42 \%$ between the high and very high priority, $29 \%$ for medium priority and a $21 \%$ between low and very low priority. 
The question on the school library facilitating access to computers has $8.3 \%$ for very low priority, a $12.5 \%$ for low priority and an $8.3 \%$ for a "no response" option. Table 4 below shows the results. Worth noting also is the percentage for very high priority $(16.7 \%)$ which is lower than the high priority (25\%). This indicates that the role of the school library in facilitating computer integration is not of very high priority to most of the school heads.

Table 4: Leadership characteristics

\begin{tabular}{|l|c|c|c|c|c|c|c|}
\hline Variable & $\begin{array}{l}\% \\
\text { Very } \\
\text { Low } \\
\text { priority }\end{array}$ & $\begin{array}{l}\text { Low } \\
\text { Priority }\end{array}$ & $\begin{array}{l}\% \\
\text { Medium } \\
\text { Priority }\end{array}$ & $\begin{array}{l}\% \\
\text { High } \\
\text { Priority }\end{array}$ & $\begin{array}{l}\% \\
\text { Very } \\
\text { High } \\
\text { Priority }\end{array}$ & $\begin{array}{l}\% \\
\text { No } \\
\text { response }\end{array}$ & Total\% \\
\hline $\begin{array}{l}\text { The school will establish a culture of } \\
\text { learning around the use of computers }\end{array}$ & 4.2 & 4.2 & 12.5 & 50 & 25 & 4.2 & 100 \\
\hline $\begin{array}{l}\text { The school library will facilitate access } \\
\text { to computers. }\end{array}$ & 8.3 & 12.5 & 29.2 & 25 & 16.7 & 8.3 & 100 \\
\hline $\begin{array}{l}\text { My school will have a computer use } \\
\text { policy }\end{array}$ & 0 & 0 & 16.7 & 45.8 & 33.3 & 4.2 & 100 \\
\hline $\begin{array}{l}\text { Computers will be integrated in } \\
\text { classroom teaching }\end{array}$ & 4.2 & 4.2 & 12.5 & 37.5 & 41.7 & 0 & 100 \\
\hline $\begin{array}{l}\text { There will be a vision statement for } \\
\text { integrating computers in the classroom }\end{array}$ & 8.3 & 4.2 & 20.8 & 33.3 & 33.3 & 0 & 100 \\
\hline $\begin{array}{l}\text { The vision statement for computer } \\
\text { integration will be drawn by all } \\
\text { stakeholders }\end{array}$ & 8.3 & 0 & 20.8 & 25 & 37.5 & 8.3 & 100 \\
\hline $\begin{array}{l}\text { The vision statement for computer } \\
\text { integration will be evaluated every } \\
\text { year }\end{array}$ & 4.2 & 4.2 & 12.5 & 45.8 & 33.3 & 0 & 100 \\
\hline $\begin{array}{l}\text { Computer skills will help students } \\
\text { access information for learning }\end{array}$ & 0 & 4.2 & 4.2 & 54.2 & 37.5 & 0 & 100 \\
\hline $\begin{array}{l}\text { Computer skills will help students use } \\
\text { information for learning }\end{array}$ & 0 & 4.2 & 0 & 66.7 & 29.2 & 0 & 100 \\
\hline $\begin{array}{l}\text { All students in my school will be } \\
\text { taught information literacy skills }\end{array}$ & 0 & 4.2 & 16.7 & 54.2 & 25 & 0 & 100 \\
\hline $\begin{array}{l}\text { All teachers in my school will be } \\
\text { trained on the use of information } \\
\text { literacy skills }\end{array}$ & 0 & 0 & 16.7 & 45.8 & 29.2 & 8.3 & 100 \\
\hline
\end{tabular}

\section{The Role of the school library}

On the question dealing with school libraries, the results show that out of the 24 schools, about $63 \%$ reported functional school libraries, while about $13 \%$ said the libraries were not functional and $25 \%$ did not respond to the question. The nonfunctional school libraries point to a weakness in the system, in terms of the implementation of government policy. According to the Revised Policy on Education 
(1994), all school libraries in secondary schools must be functional. Similarly, the lack of response to the question as evidenced by the $25 \%$ who skipped the question also is indicative of ambivalence in the area of policy, whereby school heads are probably not sure about what a functional library should be. The notion of ambivalence in policy implementation has been broached in the literature (Overman and Cahill).

The last research question aimed at finding out the perceptions of the school heads on the role of the school library in computer technology integration in the school. The responses reflect only a 33\% response to what the library is expected to be, which is the center of all learning. (Information Power: Building partnerships for learning) Of particular importance to note, is the traditional view of the library, that of provision of information, which received a response rate of $21 \%$, and even more interesting is the $17 \%$ response rate of relegating the school library to uselessness in the computer integration in the school, on account of its lack of resources. These results are indicative of a subjection of the school library to a very insignificant role in the entire school system. Table 5 below shows the results of the findings.

Table 5: Role of the Library

\begin{tabular}{|l|l|l|l|l|l|}
\hline $\begin{array}{l}\text { Provision } \\
\text { of } \\
\text { information } \\
\%\end{array}$ & $\begin{array}{l}\text { Center for } \\
\text { learning \% }\end{array}$ & $\begin{array}{l}\text { Not the library, } \\
\text { it lacks } \\
\text { resources\% }\end{array}$ & $\begin{array}{l}\text { Marketing } \\
\text { computers to users } \\
\%\end{array}$ & $\begin{array}{l}\text { No response } \\
\text { Or wrong } \\
\text { answer\% }\end{array}$ & Total \\
\hline 20.8 & 33.3 & 16.7 & 4.2 & 25 & 100 \\
\hline
\end{tabular}

The question requiring reasons for choosing particular staff to impart information skills in the school solicited varied responses. The reason for choosing the teacher librarian was based on the fact that the library keeps the information and therefore, he or she must impart the skills. The Computer Science and computer awareness teachers were chosen for their "expertise", while all the teachers were chosen because they would maximize access to computers. All these responses point to a lack of consensus as to who should impart information literacy skills. What is evident here is that there are no guidelines in the education policy as to what procedures to follow to facilitate information literacy skills. The results on table 6 below confirm the findings.

Table 6: Who should impart skills

\begin{tabular}{|l|l|l|l|l|l|}
\hline $\begin{array}{l}\text { Teacher } \\
\text { Librarian }\end{array}$ & $\begin{array}{l}\text { Computer } \\
\text { Awareness } \\
\text { Teachers }\end{array}$ & $\begin{array}{l}\text { Computer } \\
\text { Science } \\
\text { Teachers }\end{array}$ & $\begin{array}{l}\text { All Computer } \\
\text { literate } \\
\text { teachers }\end{array}$ & $\begin{array}{l}\text { All } \\
\text { Teachers }\end{array}$ & $\begin{array}{l}\text { No response } \\
\text { Or wrong } \\
\text { answer }\end{array}$ \\
\hline 12.5 & 12.5 & 12.5 & 8.3 & 45.8 & 8.4 \\
\hline
\end{tabular}




\section{Correlation between computer acceptance and leadership}

The second stage of the analysis, using Spearman's rho, sought to test the correlation significance of the computer technology acceptance and leadership variables. From the literature consulted, each of the TAM constructs had a summary statement. The computer anxiety statement was "I have control over the computer". For the PEOU the statement was "Overall I find computers easy to use", and for PU, "Overall I find computers useful in my job". These three statements were correlated to the leadership qualities statement of integrating computers in the school, integrating computers in the classroom, teaching all students computer literacy skills and the school library facilitating access to computers, as Table 7 below shows. The results of variables that show statistical significance at 0.01 and 0.05 . The results indicate that a positive correlation exists between one perceived ease of use variable (TAM) and transformational leadership. The TAM variable, "Overall I find computers easy to use", and the leadership variables; "The school library to facilitate computer access", "To have a vision statement for computer integration in the classroom", and "All students to be taught computer literacy skills were all statistically significant towards a positive correlation between the TAM and leadership. The strongest correlation is between "Overall I find computers easy to use" and " The school library to facilitate computer access” at 0.651 coefficient and 0.01 significance.

Table 7: Correlation coefficients of Computer Technology Acceptance and Leadership: Spearman's rho test: $N 24$

\begin{tabular}{|l|l|l|l|l|}
\hline Variables & $\begin{array}{l}\text { The school library to } \\
\text { facilitate computer } \\
\text { access }\end{array}$ & $\begin{array}{l}\text { Computers will be To have a vision } \\
\text { integrated in the } \\
\text { classroom }\end{array}$ & $\begin{array}{l}\text { All students to } \\
\text { statement for } \\
\text { computer } \\
\text { integration in the } \\
\text { classroom }\end{array}$ \\
$\begin{array}{l}\text { I have control over the } \\
\text { literacy skills }\end{array}$ \\
$\begin{array}{l}\text { Oomputer } \\
\text { Overall I find } \\
\text { computers useful }\end{array}$ & $0.112, \mathrm{NS}$ & $-0.96, \mathrm{NS}$ & $-0.117, \mathrm{NS}$ & $0.088, \mathrm{NS}$ \\
\hline $\begin{array}{l}\text { Overall I find } \\
\text { computers easy to use }\end{array}$ & $0.293, \mathrm{NS}$ & $-0.029, \mathrm{NS}$ & $0.130, \mathrm{NS}$ & $0.105, \mathrm{NS}$ \\
\hline
\end{tabular}




\section{Conclusions}

The objectives of this paper were to examine the principals' transformational leadership qualities and to juxtapose this to Information Technology adoption in Botswana secondary schools. In terms of information technology acceptance and use, the participants in the survey revealed a certain pattern of behavior with varying degrees of computer anxiety, perceived usefulness and perceived ease of use. At the first level, computer anxiety, the participants seemed to display very little computer anxiety, as almost all constructs showed a trend away from computer anxiety with a $70 \%$ score. The next level, perceived usefulness of the computer, seemed to produce slightly different results from the computer anxiety ones, with more school heads saying the computer is not very useful in some of their duties, because four out of the eight statements revealed a $70 \%$ trends toward computer usefulness while the other four had a $80 \%$ trend away from computer usefulness. The last level, perceived ease of use reveals less confidence in the skills related to using the computer, with only $63 \%$ agreeing that computers are easy to use from seven questions out of ten and about $42 \%$ who did not think computers are that easy to use on two out of ten questions. These findings are in line with literature in the field, which has established that "feelings of anxiety toward computers and computer use, is common, affecting 30 to $40 \%$ of the population" (Orr, p.1). The computer anxiety variable above revealed a $30 \%$ rate of computer anxiety among school heads. Also the findings point to strong indications that some school heads did not find the computer very useful in their job, neither did they feel that they had the right skills for interacting with the computer. This idea has been discussed in the literature consulted, where scholars found that computer anxiety, perceived usefulness and perceived ease of use led to low adoption and usage of computers (Vinkatesh and Morris, 2000; Szajna).

The results from the correlation test have shown that there is a statistically significant correlation between some transformational leadership statements and a perceived ease of use statement, as the results above have shown, which demonstrates that the principals who find technology easy to use are also are also those who show the most transformational leadership qualities. This concept has been discussed in the literature; with scholars pointing out that visionary leadership is necessary for the digital era and the integration of computer technology for lifelong learning. (Todd, Information Power: Building partnerships for learning) However, from the findings in the leadership variables and the open ended qualitative questions, it is also apparent that the role of the school library is relegated to a lower priority by some of the school heads. It also seems that some of the school heads do not agree on what the role of the school library and information literacy is in the school. This uncertainty and lack of agreement on the role of school libraries, is maybe indicative of policy implementation difficulties. These results have implications for policy implementation failure and seem to confirm the suggestion that though the governments in Africa have made computer technology available, it tends to be underutilized (Rose and Straub, 1998, quoting Odedra, 1993). 
In conclusion, there are strong indications that information technology adoption in Botswana secondary schools and indeed in the school library is a multifaceted problem, which requires effective leadership, and information technology policy formulation and implementation. There are several issues that are interrelated here. There is the issue of technology adoption, which affects the school heads. When the computer technology is brought into the school system, there is need to establish how technophobia will be dealt with and how to make computer technology acceptable and easy to use for all users. Added to this, is the integration of the school library in the school system. This integration depends on the leadership strategies used and functional school libraries. This makes the seemingly simple act of equipping schools with computers a very complex problem indeed. Todd, writing on the issue said,

Strategic leadership focuses on the longer term, where the scale and scope of action are school wide rather than program-focused. It demands a clear perception of role and a sense of vision. It is indicated in a long-term and futures-oriented technology plan for the school, a program of staff development that provides access to technology, and developing the staff's knowledge and skills about the pedagogy of integrating information technology into the classroom. (p.4)

From the generally mixed results of this research, it seems that the achievement of an "informed nation" (Botswana Long Term Vision 2016, p.17) needs more strategic planning in terms of information technology adoption and effective use in schools before it can be fully realized. Based on the above deliberations, a multifaceted approach targeting the information policy implementation, leadership in schools as well as the integration of the school library in the school system is suggested. 


\section{References:}

Agarwal, R. and Prasad, J. (1997). The Antecedents and Consequents of User Perceptions in Information Technology Adoption. Decisions Support Systems. 22 15-29

Baker, P.M.A. (2000) Policy bridges for the digital divide: Assessing the landscape and gauging the dimensions.” Accessed on 05/13/04 from http://www.firstmonday.org

Barbie, E (2001) The practice of social research. Australia: Wadsworth.

Baskerville R and Pries-Heje J. (2001). A Multiple-Theory Analysis of a Diffusion of Information Technology Case Information Systems Journal 11 (3) 181-212

Bolman L.G. and Deal T.E. (2003) Reframing Organizations: Artistry, Choice and Leadership. San Francisco: JosseyBass

Botswana Government: The Revised National Policy on Education - Government Paper N02 of 1994, Gaborone, March 1994.

Botswana Government website accessed on 04/12/04 from http://www.gov.bw/government/index.html

Carbo, T. (1998). “ Information Policy and the US National Information Infrastructure”. In Grieves. (Ed) Information Policy in the Electronic Age. London: Bowker.

Comin, D. and Hobjin, B. (2004) Cross-country technology adoption: Making the Theories Face the Facts. Journal of Monetary Economics. 51 (1). 39

Cresswell, J.W. (2003) Research design: qualitative, quantitative, and mixed methods approaches. London: Sage Publications.

Davis, F.D. (1989). Perceived Usefulness, Perceived Ease of Use, and User Acceptance of Information technology MIS Quarterly, 13 (3) 319-339

Dishaw, M.T. and Strong, D.M. (1999). Extending the technology acceptance model with the Task-Technology Fit constructs Information and management 36 (1). 9-21

Doyle, M. E. and Smith, M. K. (2001) 'Classical leadership', the encyclopedia of informal education. Accessed on 7/26/2004 from http://www.infed.org/leadership/traditional_leadership.htm

Gefen, D. and Straub, D.W. (1997). Gender Differences in the perception and use of e-mail: An extension to the Technology Acceptance Model. MIS Quarterly. 21 (4) 389-400

Harrison, R. (2004). The School Library: The Educational Extension. Teacher Librarian 31(3) p.63

Information Power: Building partnerships for learning. (1998) Chicago: American Library Association

Karahanna, E and Straub, D.W. (1998) The psychological origins of perceived usefulness and ease-of-us. Information and Management 35. 237-250

Kukafka, R., Johnson, S.B., Lifante, A., and Allgrante, J.P. (2003). Grounding a New Information Technology Implementation Framework in Behavioral Science: A Systematic Analysis of the Literature on IT use.

Law.N and Plomp (2003) Curriculum and staff development for ICT in Education” in Plomp, Anderson, Law and Quale, Cross-national information and communication technology policy and practices in education. Connecticut: Information Age Publishing.

Legris, P, Ingham J. and Collerette, P. (2003)“Why do people use information technology? A critical review of the technology acceptance model. Information and Management. 40 (3) p. 191-204

Long term Vision 2016; Towards Prosperity for all, 1997. Presidential Task Group, Gaborone.

Nonparametric statistics. Accessed on 02/19/2005 from http://www.statsoft.com/textbook/stnonpar.html 
Oppenheim, C. (1998). “ Current U.K. and E.U. information policy. In Grieves, M. (Ed) Information Policy in the electronic age. London: Bowker

Orr, L.V. (1993) Computer anxiety. Accessed on 01/18/2005 from http://www.usm.maine.edu/ com/lindap 1.htm

Overman, E. Sam and Cahill, Anthony G. (1990) Information policy: A study of values in the policy process. Policy Studies Review 9. p.803-818.

Rogers E.M. (1995). Diffusion of Innovations. $4^{\text {th }}$ ed. New York: The Free Press. (otherwise it would seem strange that others are quoting this book before it was published).

Rose G.M. and Straub, D.W. (1998). Predicting general IT use: Applying TAM to the Arabic World. Journal of Global Information Management, 6 (3), 39-46

Slowinski, J. (1999)“ Internet in America’s schools: Potential catalysts for policy makers. Accessed on 05/13/04 from http://www.firstmonday.org

Smith, K. (2002) Building Student Learning through School Libraries. Teacher Librarian 30(1) p.87-9

Surry, D.W. (1997). Diffusion theory and Instructional technology: A paper presented at the Annual Conference of the Association for Educational Communications and Technology (AECT), Albuquerque, New Mexico. 1215

Szajna, B. (1996) Empirical evaluation of the revised Technology Acceptance Model. Management Science, 41(1) 8592

Todd, R.J. (1999) Transformational leadership and transformational learning: Information literacy and the World Wide Web. NASSP Bulletin. 83(605) p.4-12

Venkatesh, V. and Davies, F.D. (2000). A theoretical extension of the TAM: Four longitudinal field studies. Management science 46 (2.) 186

Venkatesh, V. (2000) "Determinants of perceived ease of use: Integrating control, intrinsic motivation, and emotion into the technology acceptance model Information Systems Research. 11 (4) p.342

Venkatesh, V. and Morris, M.G. (2000). Why don't men ever stop to ask for directions? Gender, social influence, and their role in technology acceptance and usage behavior. MIS Quarterly, 24 (1) p.115-39

Zhu, K. (2003). Strategic Decisions of New Technology Adoption Under Asymmetric Information: A GameTheoretic Model. “Decisions Sciences” 34 (4) 643-675

\section{Author Note}

Angelina Totolo is a lecturer at the University of Botswana in the Department of Library and Information Studies. Currently she is pursuing a $\mathrm{PhD}$. in the College of Information at Florida State University. Her interests are in information technology adoption and how it can enhance the use of information in the solution of Africa's problems. 
Reproduced with permission of the copyright owner. Further reproduction prohibited without permission. 